
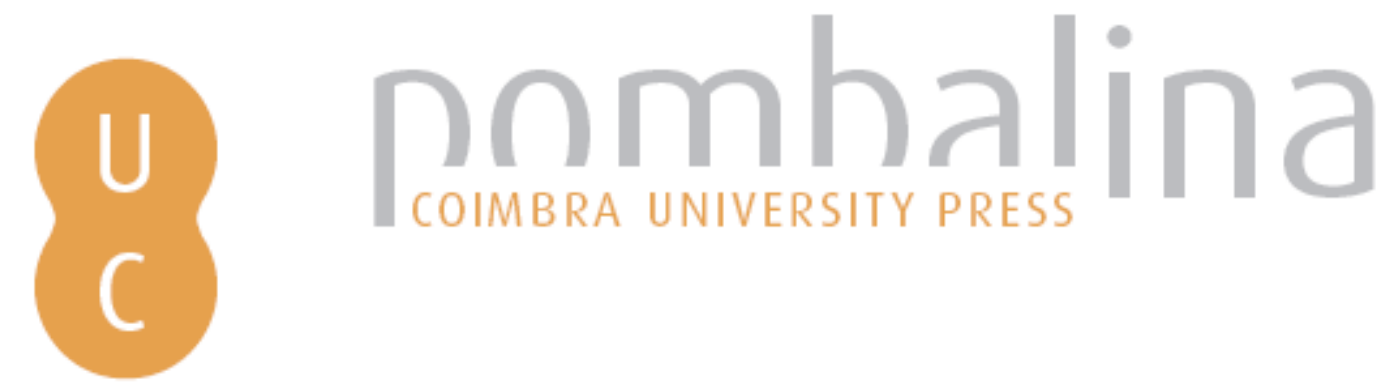

\title{
Diagnosing death by drowning through the analysis of blood markers by inductively coupled plasma: mass spectrometry
}

\author{
Autor(es): $\quad$ Santos, B.; Martins, S.; Almeida, A.; Santos, A.; Magalhães, T. \\ Publicado por: Imprensa da Universidade de Coimbra; International Academy of Legal \\ Medicine \\ URL \\ persistente: \\ URI:http://hdl.handle.net/10316.2/31800 \\ DOI: \\ DOI:http://dx.doi.org/10.14195/978-989-26-0173-1_36 \\ Accessed : $\quad$ 26-Apr-2023 02:05:33
}

A navegação consulta e descarregamento dos títulos inseridos nas Bibliotecas Digitais UC Digitalis, UC Pombalina e UC Impactum, pressupõem a aceitação plena e sem reservas dos Termos e Condições de Uso destas Bibliotecas Digitais, disponíveis em https://digitalis.uc.pt/pt-pt/termos.

Conforme exposto nos referidos Termos e Condições de Uso, o descarregamento de títulos de acesso restrito requer uma licença válida de autorização devendo o utilizador aceder ao(s) documento(s) a partir de um endereço de IP da instituição detentora da supramencionada licença.

Ao utilizador é apenas permitido o descarregamento para uso pessoal, pelo que o emprego do(s) título(s) descarregado(s) para outro fim, designadamente comercial, carece de autorização do respetivo autor ou editor da obra.

Na medida em que todas as obras da UC Digitalis se encontram protegidas pelo Código do Direito de Autor e Direitos Conexos e demais legislação aplicável, toda a cópia, parcial ou total, deste documento, nos casos em que é legalmente admitida, deverá conter ou fazer-se acompanhar por este aviso.

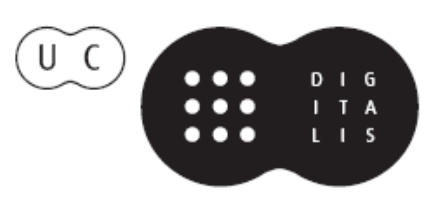




\section{Duarte Nuno Vieira Anthony Busuttil \\ Denis Cusack • Philip Beth}
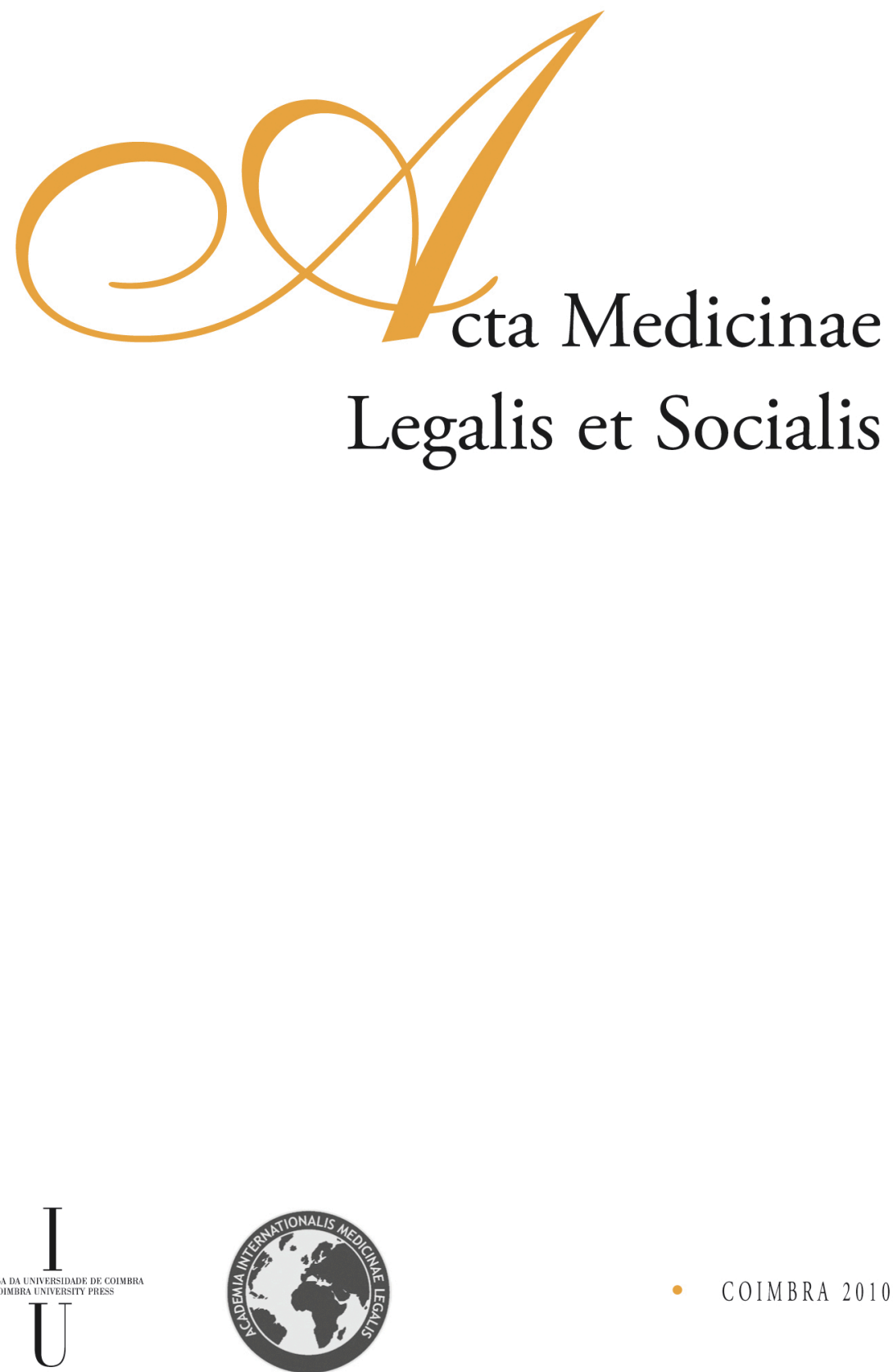
B. Santos ${ }^{1,2}$, S. Martins ${ }^{3}$, A. Almeida ${ }^{3}$, A. Santos ${ }^{4,5}$, T. Magalhães ${ }^{4,5}$

${ }^{1}$ Centre Branch of the National Institute of Legal Medicine, Coimbra, Portugal

${ }^{2}$ Faculty of Medicine, University of Coimbra, Portugal

${ }^{3}$ REQUIMTE, Department of Chemistry-Physics, Faculty of Pharmacy, University of Oporto, Portugal

${ }^{4}$ North Branch of the National Institute of Legal Medicine, Oporto, Portugal

${ }^{5}$ Faculty of Medicine, University of Oporto, Portugal

\title{
DIAGNOSING DEATH BY DROWNING THROUGH THE ANALYSIS OF BLOOD MARKERS BY INDUCTIVELY COUPLED PLASMA - MASS SPECTROMETRY
}

\begin{abstract}
Investigation of bodies recovered out of water is a complex but frequent medico-legal task. The key problem is if the victim died due to drowning or by the means of other cause and placed in water. At the moment, the diagnosis of drowning is based on some unspecific findings during autopsy (lung distension and the presence of froth in upper airways and lungs) and the results of laboratory tests. Our project aimed to evaluate the usefulness of the determination by ICP-MS of trace elements (TE) in blood of the cardiac cavities of corpses found in aquatic environment as a tool to increase the certainty of the diagnostic of death by drowning. Blood samples were collected from 18 cadavers found in water, from 20062008 , in Oporto area. The advantage of ICP-MS compared to other instrumental analytical techniques is clear and it proved to be useful. It allowed us to perform a multielemental analysis of blood, and the results highlight the importance of this kind of approach, compared to previous studies where we are dependent on the results of a single TE.
\end{abstract}

Keywords: Drowning; ICP-MS; Forensic pathology.

\section{Introduction and objectives}

Post-mortem diagnosis of drowning is one of the most difficult in forensic pathology. The majority of the diagnoses are based on some unspecific findings during autopsy (lung distension and the presence of froth in upper airways and lungs) and the results of laboratory tests [1]. Despite the many diagnostic methods used, the ideal diagnostic test as definitive proof for drowning still needs to be established, and more research is necessary. One of the diagnostic methods used is the quantification of drowning markers, such as the trace elements (TE) iron and strontium in blood [2-4]. The use of these "markers" is based on the different blood concentration between left and right heart cavities according to the type of water medium [4]. If the drowning takes place in a hypotonic medium compared to human blood (freshwater drowning) animal experimentation shows that TE blood concentration decreases in the left heart cavities as a consequence of hemodilution. On the other hand, TE such as Sr, due to its water concentration (and practically inexistence in human blood) will be higher in left ventricle (compared to the right one). Even though, the reviewed bibliographic 
data showed that strontium diagnostic value is well established in seawater drowning, but not in freshwater drowning because of the lower Sr concentration in this kind of medium [5]. The authors wish to introduce an instrumental method with recent forensic application in detection and quantification of gunshot residues [6]: Inductively Coupled Plasma-Mass Spectrometry (ICP-MS), which easily allow us to perform a multielemental analysis. So, the aims of this study are to investigate the application of other TE and their usefulness in drowning diagnosis and also evaluate Sr diagnostic value in freshwater drowning.

\section{Materials and Methods}

We collected blood samples from 18 cadavers found in water, selected from medicolegal autopsies performed in the North Branch of the National Institute of Legal Medicine (Oporto, Portugal) over the period 2006-2008. The criteria used for inclusion was based on the following aspects: the bodies had to be found in water, the absence of mortal trauma and the presence of findings compatible with drowning during the autopsy. Some cases where excluded from the study population such as those who were subjected to resuscitation maneuvers or found in advanced state of putrefaction.

The samples were collected during the autopsy, from ventricular heart cavities (after opening the pericardial sac by means of standard techniques) using disposable needle and syringe for each cavity.

The samples were then placed in propylene tubes (previously washed and decontaminated with nitric acid and deionized water) and stored at $-70^{\circ}$. Subsequently they were processed for ICP-MS analysis. About $1 \mathrm{~g}$ of blood was digested with $1 \mathrm{ml}$ of $\mathrm{H} 2 \mathrm{O} 230 \%$ and $2.5 \mathrm{ml}$ of HNO3 65\% in a microwave oven (Milestone MLS 1200 Mega). The digestion solution was diluted to $25 \mathrm{ml}$ with ultra-pure water (Milli-Q system, Millipore) and analyzed using a quadrupole ICP mass spectrometer (VG Elemental PlasmaQuad 3. The quantification of TE Li, Be, Al, V, Cr, Mn, Co, Ni, $\mathrm{Cu}, \mathrm{Zn}, \mathrm{As}, \mathrm{Se}, \mathrm{Rb}, \mathrm{Sr}, \mathrm{Mo}, \mathrm{Ag}, \mathrm{Cd}, \mathrm{Sb}, \mathrm{Cs}, \mathrm{Ba}$ and Pb (Figure 1) was performed (Si, $\mathrm{Ti}, \mathrm{Br}$ and I were also measured in the "semi-quantitative" mode). Results correspond to the content in whole blood and were expressed in $\mu \mathrm{g} / \mathrm{kg}$.

The mean difference of the TE concentration between both heart cavities was statistically compared. The $\mathrm{T}$ test for paired samples was used to evaluate the difference between the two groups. A probability level of $\mathrm{P} \leq 0.05$ was considered statistically significant.

\section{Results and discussion}

From the tested TE, some were not systematically higher (or lower) in left cavities blood versus right cavities blood, except for $\mathrm{Sr}, \mathrm{Li}, \mathrm{Cu}, \mathrm{Mn}$ and $\mathrm{Cd}$ (Figure 2 \& Table 1). Accordingly, Sr, which is typically present in water but not in blood, was found in concentrations higher in left cavities than in right cavities in 16/18 cases. So, even in the case of drowning in freshwater, where Sr is present at a lower concentration compared to seawater [5], our study points to some value of this TE, which can be complemented by another TE that behaved very similarly: Li in 15/18 cases. 
Other TE behaved the opposite way and presented a decreased blood concentration in the left cavities (compared to the right ones) as a result of the hemodilution due to the hypotonic freshwater entrance. One of the TE in these circumstances was $\mathrm{Cu}$ that presented a blood concentration in left cavities much lower than in right cavities in all the cases, with a mean difference of $411,22 \pm 434,34(\mathrm{P}=0,01)$. Additionally we were able to find other two TE that behaved like $\mathrm{Cu}$ : $\mathrm{Mn}$ in $15 / 18$ cases and $\mathrm{Cd}$ in $17 / 18$ cases. In the case of $\mathrm{Mn}$ the mean difference between both heart cavities was 37,35 $\pm 38,42(\mathrm{P}=0,01)$.

\section{Conclusions}

The advantage of ICP-MS compared to other instrumental analytical techniques is clear and it proved to be useful [7]. It allowed us to perform a multielemental analysis of blood, and the results highlight the importance of this kind of approach, compared to previous studies where we are dependent on the results of a single TE [2-3]. On these cases, whenever it isn't possible to validate the results, the conclusions also get compromised, in opposition to multielemental research where we can present reliable conclusions, even when one TE result is not significant. We were able to find "new" TE which showed a typical behavior during drowning, with $\mathrm{Cu}$ given the most promising results. The information obtained from these additional TE can complement the data obtained from classical ones ( $\mathrm{Sr}$ ). In addition we obtained consistent info regarding Sr potential in freshwater drowning. Even in this kind of medium, with the use of a highly sensitive technique such as ICP-MS [7] a higher concentration in left cavities could be observed in most cases, compared to previous studies whose sensibility didn't allowed to obtain valid results [5].

\section{References}

[1] PIETTE MH, DE LETTER EA. Drowning: Still a difficult autopsy diagnosis. Forensic Sci Int 163: 1-9, 2005.

[2] GRANDMAISON gl, LETERREUX M, LASSEUGUETTE k, ALVAREZ JC, maZANCOURT P, DURIGON M. Study of the diagnostic value of iron in fresh water drowning. Forensic Sci Int 157: 117-120, 2006.

[3] PIETTE M, TIMPERMAN J, PARSIS N. Serum strontium estimation as a medico legal diagnostic indicator of drowning. Med Sci Law 29: 162-171, 1989.

[4] AZPARren JE, VALlejo G, REYES E, HERranZ A, SANCHO M. Study of the diagnostic value of strontium, chloride, haemoglobin and diatoms in immersion cases. Forensic Sci Int 91: 123-132, 1998.

[5] AZPARREN JE, FERNANDEZ-RODRIGUEZ A, VALLEJO G. Diagnosing death by drowning in fresh water using blood strontium as an indicator. Forensic Sci Int 137: 55-9, 2003.

[6] SANTOS A, MAGALHÃES T, VIEIRA DN, ALMEIDA AA, SOUSA AV. Firing Distance Through the Analysis of the Gunshot Residue Deposit Pattern Around the Bullet Entrance Hole by Inductively Coupled Plasma - Mass Spectrometry - An Experimental Study. Am J Forensic Med Pathol 28: 24-30, 2006.

[7] GOULlE JP, MAHIEU L, CASTERMANT J, NEVEU N, BONNEAU L, LAINE G, BOUIGE D, LACROIX C. Metal and metalloid multi-elementary ICP-MS validation in whole blood, plasma, urine and hair Reference values. Forensic Sci Int 153: 39-44, 2005. 


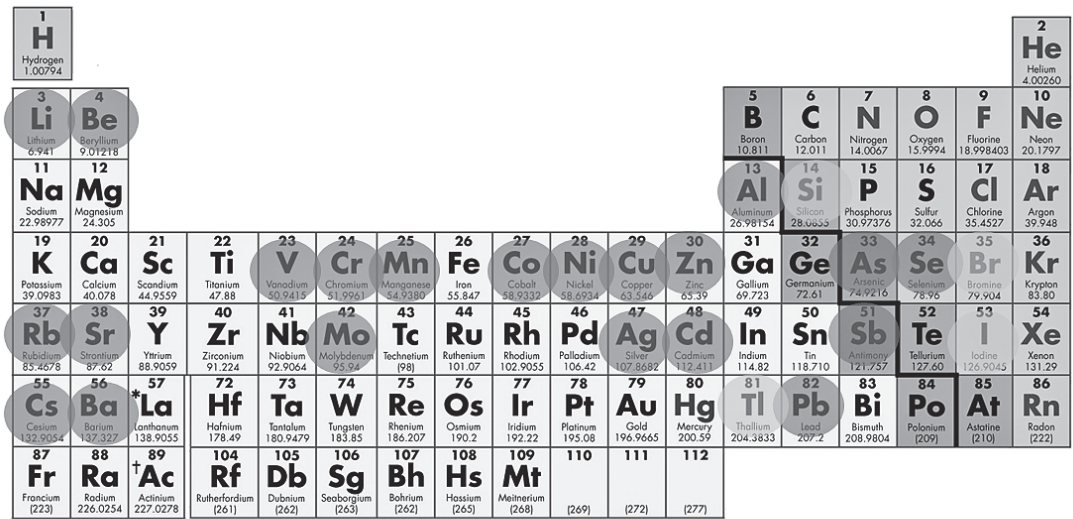

\begin{tabular}{|c|c|c|c|c|c|c|c|c|c|c|c|c|c|c|}
\hline *Lanthanide Series & \begin{tabular}{c|}
$\mathbf{5 8}$ \\
$\mathbf{C e}$ \\
Cerium \\
\end{tabular} & $\underset{\text { Prosodymium }}{\mathbf{5 9}}$ & $\begin{array}{c}\mathbf{6 0} \\
\mathbf{N} d \\
\text { Nodrymium }\end{array}$ & $\begin{array}{c}\text { Prm }^{61} \\
\text { Promentive }\end{array}$ & $\mathbf{S i m}_{\substack{\text { Somorium } \\
\text { sisum }}}^{\mathbf{6 2}}$ & \begin{tabular}{|c|c}
$\mathbf{6 3}$ \\
Europium \\
Eus
\end{tabular} & $\underset{\substack{\text { Goddinium } \\
\text { Cof }}}{64}$ & $\mathbf{T}_{\substack{\text { Tethium } \\
\text { teco }}}^{65}$ & $\begin{array}{c}66 \\
\text { Dy } \\
\text { Dysprosium }\end{array}$ & Ho & 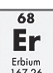 & $\mathrm{Tm}_{\substack{\text { Thulium } \\
\text { tholum }}}$ & 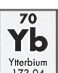 & $\begin{array}{c}71 \\
\text { Luetivm } \\
\text { cutelium }\end{array}$ \\
\hline${ }^{\dagger}$ Actinide Series & \begin{tabular}{|l|}
140.115 \\
$\mathbf{9 0}$ \\
Th
\end{tabular} & $\begin{array}{c}140.9077 \\
\mathbf{9 1} \\
\mathbf{P a}\end{array}$ & $\begin{array}{l}144.24 \\
\mathbf{9 2} \\
\mathbf{U}\end{array}$ & \begin{tabular}{|c|}
$1(15)$ \\
$\mathbf{9 3}$ \\
$\mathbf{N p}$
\end{tabular} & \begin{tabular}{|l|}
$\mathbf{1 5 0 . 3 6}$ \\
$\mathbf{9 4}$ \\
$\mathbf{P u}$
\end{tabular} & \begin{tabular}{|c|}
151.955 \\
$\mathbf{A m}$
\end{tabular} & \begin{tabular}{|c|}
57.25 \\
$\mathbf{C m}$
\end{tabular} & $\begin{array}{l}158.9254 \\
\mathbf{9 7} \\
\text { Bk }\end{array}$ & \begin{tabular}{|c|}
62.50 \\
$\mathbf{C 8}$ \\
\end{tabular} & \begin{tabular}{|l}
16.99303 \\
$\mathbf{9 9}$ \\
\end{tabular} & $\begin{array}{l}100 \\
F m\end{array}$ & $\begin{array}{l}10.834 \\
\text { Md }\end{array}$ & \begin{tabular}{|c|}
102 \\
No
\end{tabular} & $\begin{array}{l}103 \\
\mathbf{L r}\end{array}$ \\
\hline & $\begin{array}{l}\text { Thorivm } \\
\text { 233.0381 }\end{array}$ & $\begin{array}{l}\text { Prolotinivm } \\
233.0359\end{array}$ & $\begin{array}{l}\text { Uatanim } \\
\text { 239.0289 }\end{array}$ & $\begin{array}{c}\text { Noponum } \\
\text { 237.048 }\end{array}$ & 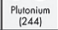 & 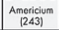 & 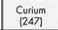 & 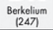 & Folitarsium & : : nstaninum & 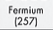 & $\begin{array}{l}\text { Sonddobsium } \\
{[258)}\end{array}$ & 2 & 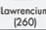 \\
\hline
\end{tabular}

Figure 1 - Periodic table showing quantified TE

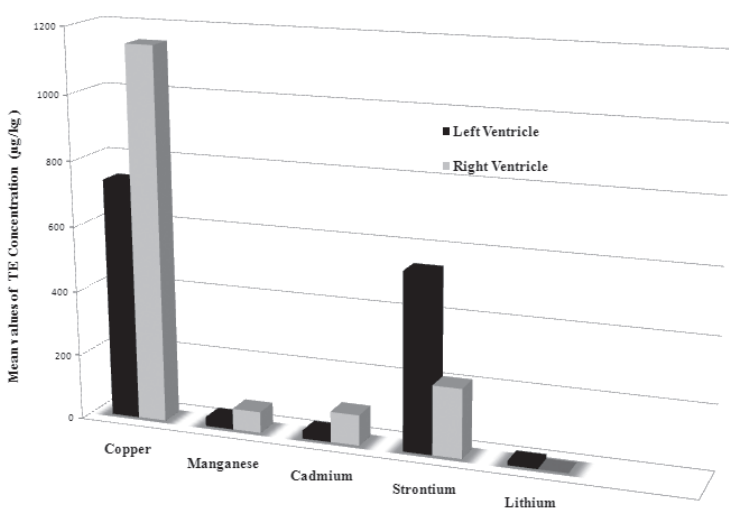

Figure 2 - Graphic of mean TE concentrations in left ventricle vs. right ventricle

\begin{tabular}{|c||c||c||}
\hline TE & LV mean & RV mean \\
\hline \hline$C u$ & $737,33 \pm 225,15$ & $1148,56 \pm 448,01$ \\
\hline \hline$C d$ & $25,53 \pm 33,87$ & $95,05 \pm 134,08$ \\
\hline \hline$M n$ & $28,61 \pm 11,12$ & $65,95 \pm 38,03$ \\
\hline \hline$S r$ & $545,38 \pm 942,17$ & $213,63 \pm 290,02$ \\
\hline \hline$L i$ & $13,12 \pm 21,08$ & $5,5 \pm 7,3$ \\
\hline
\end{tabular}

Table 1 - Mean TE concentrations values in left ventricle vs. right ventricle 